\title{
EVALUATION OF COST ESTIMATION TECHNIQUES IN DRC VALUATION: A COMPARATIVE ASSESSMENT OF VALUERS AND QUANTITY SURVEYORS IN LAGOS STATE
}

\author{
Vincent Uwaifiokun AIHIE ${ }^{1}$, Matthew IKUABE ${ }^{2}$ \\ ${ }^{1}$ Department of Estate Management, University of Benin, Benin City, Nigeria \\ ${ }^{2}$ Department of Quantity Surveying, University of Benin, Benin City, Nigeria \\ Corresponding author`se-mail:uwaaihie@yahoo.com
}

\begin{abstract}
The aim of the research is to comparatively assess the knowledge and competency levels among valuers and quantity surveyors of cost estimation techniques used in DRC valuation. The study investigates the need for estate surveyors and valuers in Nigeria to improve their current knowledge of cost estimation techniques when valuing non-rent yielding and specialized properties using the DRC method of valuation. More importantly, it evaluates the need for valuers to engage in the services of quantity surveyors in order to ensure that accurate cost estimates are provided for use in the valuation process. The research methodology adopted in actualizing the aim of the present study made use of primary and secondary sources of data, which included texts, published research work and semi-structured questionnaire. Identical questionnaire was distributed to both valuers and quantity surveyors in Lagos and their responses were measured using statistical tables and simple percentages. A proficiency scale of the National Institute of Health was adopted to test the level of competence of cost estimation techniques amongst valuers and quantity surveyors and their responses were ranked. Furthermore, a two-sample t-test was used to compare the means of random samples drawn from the responses of these two populations. The findings showed that there was a lack of awareness more on the part of valuers than quantity surveyors when it came to the knowledge and use of current cost estimating methods when valuing properties using the DRC method of valuation. These findings also gave credence to the fact that the services of quantity surveyors most times were not commissioned when these cost estimates were to be determined for valuation, hence leading to properties being undervalued or overvalued. In a nutshell, the recommendations postulated dwelt on improving the cost estimating knowledge of estate surveyors and valuers through seminars, symposiums and workshops organised by NIESV and NIQS, awareness of the need for valuers to work with quantity surveyors to perfect valuation briefs involving the use of the DRC method and slight changes made to the curriculum of the study course "Estate Management" in tertiary institutions so as to accommodate taking courses in quantity surveying.
\end{abstract}

Keywords: Depreciated replacement cost, estate surveyors \& valuers, quantity surveyors, valuation, cost estimation techniques, level of competence. 


\section{INTRODUCTION}

The estate surveyors and valuers are the only recognised professionals permitted by law to carry out the valuation of properties in Nigeria (Estate Surveyors and Valuers [Registration, etc.] Act, 2007). "Real estate professionals (valuers/appraisers henceforth) are often instructed by their clients to appraise their properties, because they are trained in, knowledgeable of and experienced in the real estate market which is imperfect, heterogeneous, has complex legal interest and complicated real estate laws" (Shapiro et al., 2012). These properties range from owner-occupied to income producing properties and non-income producing properties. Valuing income producing property is pretty straightforward as the passing rent from such a property is usually capitalized to arrive at its open market value. This method of valuation widely referred to as the investment method of valuation can only suffice when there is rent passing on the property. In a situation whereby the property is owner occupied or falls into the category of non-income generating properties such as public schools, churches, hospitals, which are not subject to market potentials and whose value would be impracticable to obtain in relation to comparables, the Depreciated Replacement Cost (DRC) method becomes a more reliable method to determine the true value of the property. The DRC method also known as the contractor's method of valuation takes into account the unit cost (replacement cost) of the property before depreciating and adding the value of the land (IVSC, 2017). The unit cost in practice by most estate surveyors and valuers especially in Nigeria is either done by calculated guesswork or face value. Most times the unit cost is obtained from 'experience' having carried out similar valuations on comparable properties (Aihie, Ikuabe, 2018). Determining the unit cost of construction or cost estimates for valuation from experience as against resorting to the services of qualified quantity surveyors at the end of the day leads to the property being overvalued or in most cases undervalued. The aim of the present research is to investigate the level of awareness and competency levels of cost estimation techniques among professional estate surveyors, valuers and quantity surveyors when using the DRC method of valuation.

\section{METHODS OF VALUATION}

To enable professional estate surveyor and valuers to effectively carry out their statutory functions of valuing properties, the IVSC (2017), based on the economic principles of price equilibrium, anticipation of benefits and substitution, identified three principal valuation approaches:

- investment approach;

- market approach;

- cost approach.

According to IVSC (2017), "the cost approach provides an indication of value using the economic principle that a buyer will pay no more for an asset than the cost to obtain an asset of equal utility, whether by purchase or by construction, unless undue time, inconvenience, risk or other factors are involved. The approach provides an indication of value by calculating the current replacement or 
reproduction cost of an asset and making deductions for physical deterioration and all other relevant forms of obsolescence".

Ifediora (2009) further explained that the replacement cost method was used to determine property value by reference to cost of reproduction or equivalent reinstatement cost of the property. In the cost approach, the value of land is first determined, the depreciated reproduction cost of the building and infrastructural improvements is then added to it in order to arrive at a value. The cost of land and construction plus an entrepreneurial profit will be the upper limit of the value of the property being valued but if the subject property is not new and suffering from some obsolescence, it is argued that the prudent buyer will insist on paying less than the cost of a new building without depreciation (Kuye, 2011).

The DRC method is "best used when improvements are new and there is adequate pricing information to value the property components. This approach may be less desirable if there are no recent sales of vacant land for which to compare, since the major method of valuing vacant lands is to use the sales comparison approach, or when constructions are not readily available" (Aihie, Ikuabe, 2018; Onyejiaka et al., 2015; Wyatt, 2009).

Properties for which comparables are not readily available in determining their open market values either by market comparison or income capitalization method easily pass the test of the contractor's method. Some of these special properties include public schools, churches, barracks and town halls. The price as highlighted by Udechukwu (2009) that anyone might be reasonably willing to pay for any of this class of properties is the amount it would cost him to erect a similar one elsewhere.

According to Kuye (2011), by applying the contractor's method (to obtain market value), the valuer will:

1. decide if the objective of valuation is to determine the reproduction cost of an identical building with all its defects and advantages or the value of a comparable building capable of producing a similar level of utility-replacement cost;

2. determine whether production or replacement is appropriate;

3. determine the production or replacement cost of the structure being valued;

4. find the cost of any site improvements;

5. estimate the appropriate monetary amount of depreciation discount necessary to adjust the construction cost (new) for any depreciation observed in the property being valued;

6. deduct the depreciation allowances from the cost new of the structure and the site improvements;

7. add the market value of the land to the depreciation cost of the improvement and site improvement;

8. add an allowance for developer's profit to the last figure obtained above if this item has not been built into the cost

Determining the Replacement Cost of a Building are described in the next subpart. 


\subsection{Determining the Replacement Cost of a Building}

The determination of the replacement cost poses some difficulties as most times the valuer has to take into consideration the price of a modern substitute with the same facilities as the subject property and providing the same utility. The modern substitute should be at par in terms of construction materials used, design, technology and in most cases services offered in the subject property (Plimmer, Sayce, 2006). Basic to arriving at the cost of replacement is first an estimate of the reproduction cost new as at the date of appraisal.

Likewise, the American Society of Appraisers (2010) stated that the current cost of constructing a similar property equal to the existing structure being valued in quality and utility taking into consideration current prices, standards of materials and designs could be defined as replacement cost. Ogunba (2011) opined replacement cost as "the cost of erecting a building having the same utility as the original, without necessarily reproducing exactly the same characteristics of the property, but using today's materials, labor, and building techniques. In other words, replacement cost represents the cost to create an equally desirable substitute property. Reproduction cost, on the other hand, is the cost of exact duplication of a property as of a certain date. Reproduction cost is sometimes difficult to measure because the same building materials or methods may not be available". Reproduction envisages faithful copy while replacement focuses on equivalent substitute, hence replacement cost is usually lower than reproduction cost. Replacement costs are those costs which would actually be incurred in replacing the property or its substitute. It is therefore equivalent reinstatement at the current prices and not historic cost of construction. Whether we are dealing with replacement or reproduction costs, direct building costs and indirect building costs are usually considered. "Direct building costs include costs of materials and labour generally including the contractor or sub-contractors overhead and profit while indirect costs include transport costs, installation costs, professional services, developer's overhead, finance costs (interest on debt financing) and profit margin/entrepreneurial profit to the creator of the asset" (IVSC, 2017). The indirect cost has to be considered even though the building is already in existence, because these costs would have been borne and at today's rates if the building were to be built now. For a just completed building with accurate records, the cost of development constitutes the replacement or reproductive costs; therefore, for an existing property, the historic cost of production, as we noted earlier, is no longer valid.

\subsection{The Use of DRC Method in Nigeria}

French and Gabrielli (2007) argued that in the UK, the DRC test was regarded as a method of "last resort" by valuation professionals because of the difficulty it posed in deriving information for valuing properties. Although the DRC method is seen as a less uncertain method of valuation in the UK, in continental Europe the cost approach (DRC) is often the predominant method of valuation and has always been considered to produce values parallel to the market. In the Nigerian financial 
market, valuation for mortgage purposes is the valuation most frequently requested for as lenders often require interest in real property as collateral to secure mortgage loans (Udoekanem, 2018).

Investigations carried out by Akomolede (2004) confirm that three out of the traditionally five known methods of valuation are popular among valuation practitioners in Nigeria. They are investment, comparative and cost methods. According to the same author, ,these three traditional methods rely on net income, recent sale prices and replacement cost data respectively to provide indications of value". Out of the five methods of valuation practiced by valuers in Nigeria today, the DRC method has become the rule of thumb whether the property is an income generating property or a specialized property with no comparables in the market. Ekenta and Iroham (2014) investigated the challenges of mortgage valuation in Port-Harcourt and found that the majority of the estate surveying and valuation firms surveyed (59\%) adopted the DRC method in mortgage valuation in the city. In the same vein, a study carried out by Onyejiaka et al. (2015) on the challenges of using cost method of valuation in selected residential and commercial properties in Awka attested to the prevalence of the cost method as the most preferred method of valuation among valuers. The reason is not far-fetched as unlike other matured property markets all over the world, the Nigerian property market is not a very transparent one. It is characterised by a lack of sales on comparable properties with no reliable databanks of capitalization rates to correctly base market value on. Although Ifediora (2009) and Ogunba (2013) argued that cost in the investment sense was not value as the DRC method could not account for the interrelationship of utility, scarcity, desire and purchasing power. Bello and Bello (2007) stated that in the current Nigerian situation, "the depreciated replacement cost method of valuation produces estimates that are closer to market prices and is therefore a more realistic and appropriate method of valuing properties in the current economic circumstances". With the Nigerian property market still trying to slowly recover from the 2015 recession that hit the economy, it is safe to state that the DRC method of valuation in the light of high building costs and vacancy rates would reflect the true values of properties both to investors and owners alike. It has been argued that "the replacement cost method is used when there are insufficient market data to support a valuation estimate, then, on the other, that the output is market value because it is based on market-derived valuation inputs. It is difficult to understand how the existence of markets in factor inputs (construction costs, land prices) in the valuation model means that the output is a market valuation" (Wyatt, 2009). To validate these market derived valuation inputs, Whipple (1995) suggested that building costs be derived from the construction market rather than the real estate market; these costs he believed would be influenced by different market forces even before depreciation was estimated. Onyejiaka et al. (2015) affirmed that most valuers derived information on the unit cost of construction from personal assumptions and calls made to other valuers. Ifediora (2009) opined that although the quantity surveying method was expensive and time consuming, it provided the most accurate method of estimating replacement cost of a property as it took into consideration every item involved in the construction of the property, including labour. 


\subsection{The Quantity Surveyor}

"A quantity surveyor is a professional in the construction industry who has the ability to analyse both cost components and practical physical construction works of a project in a successful way so as to be able to apply the results of his analysis in solving problems peculiar to each project" (Nkado, 2000). The Nigerian Institute of Quantity Surveyor (NIQS) (2015) defines the profession of quantity surveying as "being responsible for total cost and procurement management, for the achievement of client's objectives in all types of capital projects and developments, from conception to commissioning and maintenance". Olatunde (2006) summarised the duties of quantity surveyor to include estimating building costs, preparing tender documents and negotiating construction contracts. With nations embarking on developmental projects daily, the role of the quantity surveyor cannot be overemphasised as he brings a level of sanity to the incidence of rising cost so as to ensure sustainable national development (Olatunde, Okorie, 2016). Nigeria is no exception as research has shown that even licensed commercial banks ranked valuers and quantity surveyors top among professionals responsible for valuation of landed properties used as security for bank loans (Okorie et al, 2012).

Jagboro (2016) insists that quantity surveyors as construction experts should be at the inception and delivery of any construction project to ensure financial probity and accountability.

\subsection{Methods of Estimating Costs}

Professionally, the work of estimating cost of construction belongs to the quantity surveyors or cost accountants as they are sometimes called. For the valuation by cost approach of a major development, the valuer should obtain the cost estimate from the consultant quantity surveyor. For most valuations, however, the valuer produces his cost estimate using less complicated forms of costing.

According to Breedt (2010) and Simon-Eigbe (2003), the methods of cost estimating include:

1. cost-per-unit method of estimating;

2. square-metre method of estimating;

3. rough or inclusive-quantities method of estimating;

4. storey-enclosure method of estimating;

5. cube method of estimating;

6. elemental method of estimating;

7. comparative estimating;

8. interpolation estimating.

Cost-per-Unit Method of Estimating is described further.

\subsection{Cost-per-Unit Method of Estimating}

"In the cost-per-unit method, the estimate of total building cost can be obtained by multiplying the use-factor of a project by an "all inclusive" monetary rate based

on historical records. Examples of use factors include the number of keys/rooms in a hotel, the number of beds in a hospital, the number of people to be accommodated 
in a restaurant, etc." (Breedt, 2010). This method of cost estimating takes into account the fact that there is a close relationship between a construction project as a whole and the number of functional units that it can support (Ashworth, Perera, 2015). "Functional units are those factors which express the intended use of the building better than any other. This method is extremely useful on occasions where the valuer requires a preliminary estimate based on little more information than the basic units of accommodation" (www.qskiru.blogspot.com). Cost-per-unit method is more applied to specialized buildings such as hospitals, sports buildings, parking lots, theatres and hotels. It is useful to the valuer through the replacement cost method of valuation, pre-investment studies before the detailed working drawings are prepared, of proposed building projects and in the valuation of the aforementioned specialized kind of properties. The major problem of this method, based as it is on the analysis of past comparable constructions, is the difficult task of computing the unit rate. This involves making allowance for the whole range of factors from shape and size of building to constructional methods, materials, finishing and fittings (Ifediora, 2009).

\subsection{Square-Meter Method of Estimating}

This method is also known as the superficial/floor area method; the estimate of construction cost is obtained by multiplying the total construction area by a monetary rate; total floor area is measured between internal faces of external walls and a unit rate based on the current or historical comparables and is then multiplied by the total floor area to obtain the likely cost of the building; it is pertinent to note that the measurements between the internal faces enclosing external walls make no deductions for internal walls, partitions, stairs, landings, lift shafts, passages, etc. (Breedt, 2010; Ifediora, 2009). Although easy to apply, the square-metre method comes under scrutiny when used in trying to estimate cost of certain buildings such as warehouses or open offices. The accuracy rate in such instances was found to be less than $15 \%$ (Brook, 2017). It is also possible to have different unit rates for separate areas where there is distinct variability in constructional methods and quality of finish. Consideration must also be given to varying storey heights in assessing unit rates and when extracting rates from cost analysis (Ifediora, 2009).

\subsection{Rough or Inclusive-Quantities Method of Estimating}

This method places emphasis on estimating the cost of items similar to each other as a group instead of individually. "The areas of the earth filling under floors, surface bed, screed, floor finish, etc. are not exactly the same but sufficiently similar to permit them to be grouped together. Sundry items of little value are not measured but are allowed for as a percentage" (Pienaar, 2004), and detailed information such as working drawings are required by which time it would be possible to do an estimate using the elemental estimate method, or measure provisional bills of quantities. Although this method can be used to supplement other systems of estimating, it requires a certain level of skill and experience to determine the items to be put forward for costing and the ones which can be ignored (Breedt, 2010). 


\subsection{Storey-Enclosure Method of Estimating}

This method was introduced as a result of the work of RICS (Royal Institute of Chartered Surveyors) study group on a new method of a single price rate approximate estimating with the aim of overcoming the drawbacks of the methods so far in use (Ifediora, 2009). "It consists of measuring certain areas such as the floor area, the roof area, the vertical external wall area, etc. and multiplying each of these areas by a pre-determined factor for each item" (Breedt, 2010). Items such as plumbing and sanitary fittings, joinery fittings, etc. are separately measured and estimated, and Ifediora (2009) highlighted the rules for using this method:

- ground floor area to be multiplied by a weighing factor of 2;

- the area of floor measured on plan;

- the area of external walls;

- the area of basement floor to be multiplied by a weighing factor of 3;

- the area of upper floors multiplied by a factor of 2 plus $0.15 n$ th, $n$ representing the number of floors.

Items not directly related to the enclosure by the external walls should be dealt with separately, for example, external works, drainage, unusual foundation such as pilling, engineering services and so on. The storey-enclosure method is similar to the superficial method and only varies in more precise measurement of the space enclosed in the building.

\subsection{Cube Method of Estimating}

The cube method of estimating involves the calculation of the cubic content of the building using prescribed rules of the Royal Institute of British Architects (RIBA). This method unlike the floor area method does not take into account the height of storeys; instead it assesses the volume of the building as a whole. "Buildings with distinct types of occupation should have corresponding volumes assessed separately, for example, car park areas, shopping areas and office areas in a commercial building. Specific works like excavations, foundations and external works ought to be assessed separately by using cost comparisons or approximate quantities, for example. Costs per cubic meter may be difficult to find in countries where the method is not current. Actually, such costs depend on a number of variables, like building types, proportion of wall area per floor area, quality of finishes and so on. Calculation of volume is subject to rules of measurement (www.qskiru.blogspot.com):

- measured from external faces of external walls;

- height of the building is taken from the top of foundation:

1. for pitched roof:

a. a point midway between the ceiling and the apex of roof $2 / 3$ where roof space is un-occupied.

b. a point three quarters from the ceiling to the apex of the roof where roof space is occupied

2. for Flat roof;

a. a point $0.61 \mathrm{~m}$ ( 2 feet $)$ above the roof structure". 
"All projections such as porches, steps, bays, dormers, projecting roof lights, chimney stacks, tank compartments on flat roof and similar features, shall be measured and added to the cubic content of the main building" (Ifediora, 2009). The volume of the building so obtained is then multiplied by the unit rate to obtain the cost estimate.

\subsection{Elemental Method of Estimating}

According to this method, the building is divided into elements such as foundations, structural frame, external envelope, internal divisions, floor finishes, etc.; each element is subdivided into components; using superficial or floor area single price rate, the overall unit cost is broken down into elements and subelements, thus making it possible to adjust for differences in design and quality of components (Ifediora, 2009).

Quantity surveyors commissioned by valuers most often than not use this method to provide bills of quantities of major development works (Ifediora, 2009).

\subsection{Comparative Method of Estimating}

This estimating method takes into consideration the "cost of a similar type of building as a basis and then to make cost adjustments for variations in constructional methods and materials. For this purpose, it is advisable to build up costs usually related to a square-meter of finished work for a whole range of alternatives, to enable speedy adjustments to be made when preparing approximate estimates" (Seeley, 1976).

\subsection{Interpolation Method of Estimating}

This is a variant of the comparative method. "The estimate of probable cost is produced by taking the cost per square meter of floor area of a number of similar type of buildings from cost analyses and cost records and interpolating a unit rate for the proposed building" (Hore, Kehoe, McMullan, Penton 1997).

\subsection{Use of 'As-built Drawings'}

For the purpose of making estimates when making use of DRC method of valuation, one reliable way to achieve this is making use of 'as-built drawings'. When a building project is to be carried out, the architect is commissioned or engaged to prepare the drawings of the intended project. As work progresses on site, variations can be encountered which brings about a shift from the initial drawing at the inception of the project. Hence, it is wise that at the completion of the project, the architect prepares 'as-built drawings' of the completed building/property.

In the advent of carrying out valuation using the DRC method, the use of these 'as-built drawings' would go a long way in aiding the quantity surveyor to prepare cost estimates for the valuer, taking into account changes in prices of materials and labour remuneration. 


\section{RESEARCH METHODOLOGY}

A survey/questionnaire research method was employed for this study. The sample for the study comprised registered valuers and quantity surveyors in Lagos state. Lagos metropolis located in the South-western part of Nigeria is the country's former administrative capital. Despite the movement of the Federal Capital to Abuja in 1990, it has the single largest concentration of Nigeria's commerce, industrial and service activities (Olunloyo, 2012). These services which include those rendered by professionals in the built-up environment like valuation and quantity surveying have about 50 \% of their firms' head offices domiciled in Lagos. This makes Lagos state a fertile ground from which to elicit adequate responses from both registered valuers and quantity surveyors on the subject of the present research. Two similar sets of closed-ended questionnaires were distributed to the study sample. Type 'A' questionnaire was administered on registered valuers to gather data on their level of awareness/understanding of cost estimating techniques and also how they determined replacement cost when carrying out valuations using DRC method. Type ' $\mathrm{B}$ ' questionnaire was administered on registered quantity surveyors to elicit how often quantity surveyors were commissioned by valuers when seeking information on replacement cost and the opinion of quantity surveyors on whether their inputs in the DRC valuation process would make the use of the method more accurate. A total of 70 questionnaires were administered to the study sample. Out of the 70 questionnaire that were distributed, 62 questionnaires (35 for estate surveyors and valuers and 27 for quantity surveyors) were completed and returned. The 62 questionnaires that were returned and analysed represent $89 \%$ of the response rate. Both descriptive and inferential statistics were used to analyse the responses. A proficiency scale of the National Institute of Health was adopted to test the level of competence of cost estimation techniques amongst valuers and quantity surveyors. "The NIH proficiency scale is an instrument used to measure one's ability to demonstrate a competency on the job. The scale captures a wide range of ability levels and organises them into five steps: from "Fundamental Awareness" to "Expert" (National Institutes of Health, 2018). Within the framework of the present research, the NIH scale is as follows:

5-Expert (Mean competency level is ranked between 1-2);

4-Advanced (Mean Competency level is ranked between 3-4);

3-Intermediate (Mean Competency level is ranked between 4-5);

2-Novice (Mean Competency level is ranked between 5-6);

1-Fundamental Awareness (Mean Competency level is ranked between 7-8).

Furthermore, an independent two-sample t-test was carried out to compare the means of the responses from professionals.

"The data analysis carried out comprised computation of the mean scores, standard deviation and group independent two- sample t-test analysis of the dependent variables. The two-sample t-test is used when data from two-sample of participants or respondents is tested to know whether the mean of the population from which the sample is drawn is the same as or significantly deviant from the hypothesized mean" 
(Coates et al., 2001). Carrying out a two-sample t-test, the following assumptions are made:

1. the data are continuous (not discrete);

2. the data follow the normal probability distribution;

3. the variances of the two populations are equal (If not, the Aspin-Welch Unequal-Variance test is used.);

4. the two samples are independent. There is no relationship between the individuals in one sample as compared to the other (as there is in the paired t-test);

5. both samples are simple random samples from their respective populations. Each individual in the population has an equal probability of being selected in the sample" (NCSS Ltd., 2018).

\subsection{Research Question}

The question posed in the present research is: Are valuers likely to have a better level of expertise on cost estimating methods than quantity surveyors?

\subsection{Hypothesis}

The hypothesis proposed for this study for the two independent groups is:

H0: There is no significant difference between the level of expertise on cost estimating methods between valuers and quantity surveyors

Test: The hypotheses for the comparison of two independent groups are:

Ho: $\mathrm{u} 1=\mathrm{u} 2$ (means of the two groups are equal)

The null hypothesis for the independent $t$-test is that the population means from the two unrelated groups are equal (Field, 2005) and,

Ha: $\mathrm{u} 1 \neq \mathrm{u} 2$ (means of the two group are not equal)

The null hypothesis for the independent t-test is that the population means from the two unrelated groups are unequal (Field, 2005).

\subsection{Decision Rule}

"When the p-value is less than $0.05(p<0.05)$ then the difference between the two means is statistically significant and that there is evidence to reject the null hypothesis in favour of the alternative. On the other hand, when the p-value is greater than $0.05(p>0.05)$ then the difference between the two means is not statistically significant and the null hypothesis is accepted" (Coates et al., 2001; Field, 2005).

\section{RESULTS}

The findings of the study were discussed based on responses from the distributed questionnaire, the research questions answered and the hypothesis tested.

Findings show that $91.4 \%$ of valuers who responded have been in practice for more than 10 years as against $22.2 \%$ of quantity surveyors. There was no valuer among the respondents who had practiced below 5 years while $22.2 \%$ of respondents representing quantity surveyors affirmed that they had been in practice 
for less than 5 years. $55.6 \%$ of the respondents show that there are more quantity surveyors who have practiced between 5-10 years as against $8.6 \%$ of valuers in this category. From the findings, it can be inferred that there is more awareness about the profession of estate surveying and valuation than quantity surveying. The proportion of valuers as against quantity surveyors who have been in practice for a longer period of time also lays credence to the fact that there are more individuals willing to tow the path professionally as valuers than as quantity aurveyors.

In terms of being conversant with current cost estimating methods, $96 \%$ of respondents representing quantity aurveyors showed that they were familiar with current cost estimating methods as against the $93.8 \%$ of valuers who affirmed knowledge about cost estimating methods. Although both professionals showed a high level of familiarity with current cost estimating methods, quantity aurveyors seemed to have an upper hand by virtue of their training and profession.

Executing projects, $53.3 \%$ of the respondents representing quantity surveyors showed that they had worked with valuers on project consulting. This was as against $20 \%$ each that revealed that they had only be involved with valuers on project valuation and cost estimation. It can be inferred that most of the time valuers do not work directly with quantity surveyors on projects. This is evidenced by the term 'valuation' which to the valuer means determining the monetary worth of a property while to a quantity surveyor it means determining the amount payable to a contractor after a certain phase of construction.

Findings also revealed that $14.7 \%$ of valuers were more likely to engage quantity surveyors when determining cost estimates than $2.9 \%$ who never did. It is also interesting to note that the proportion of valuers at $41.2 \%$ who would likely engage quantity surveyors when determining cost estimates for DRC valuation was equal to the number of those who would engage them once in a while. The reason could stem from personal preference or the availability of a quantity surveyor as at the time the DRC valuation was to be carried out.

Table 1. Sources of Information on Reinstatement Cost

(developed by the authors)

\begin{tabular}{|c|c|c|c|}
\hline Respondents & Responses & Frequency & Percentage \\
\hline \multirow[t]{6}{*}{ Valuers } & Comparables from judgement \& experience & 16 & 25.8 \\
\hline & Information from other estate surveyors \& valuers & 10 & 16.1 \\
\hline & Use of current cost estimating methods & 15 & 24.2 \\
\hline & $\begin{array}{l}\text { Resorting to the services of registered quantity } \\
\text { surveyors }\end{array}$ & 19 & 30.6 \\
\hline & Other & 2 & 3.23 \\
\hline & Total & 62 & 100 \\
\hline
\end{tabular}

The data in Table 1 reveals the sources valuers are likely to reach out to when seeking information on reinstatement cost to carry out DRC valuation. The findings show that $25.8 \%$ of the respondents would seek out information from judgement 
and experience while $30.6 \%$ would engage registered quantity surveyors. $16.1 \%$ of the respondents would seek out information from other valuers while $24.2 \%$ would make use of current cost estimating methods. It can be reasonably inferred from the findings that although valuers still reach out to quantity surveyors when trying to determine reinstatement cost, there is still a growing number of valuers that would settle for information from personal judgement and experience. As the proportion of valuers that would make use of current cost estimating methods shows, there are still very few valuers who are conversant and competent with using contemporary cost estimating methods and this can be attributed to a lack of training.

Table 2. Competency Level Rankings of Cost Estimating Methods between Valuers \& Quantity Surveyors (developed by the authors)

\begin{tabular}{|c|c|c|c|c|c|}
\hline & Profession & $\mathbf{N}$ & Mean & Ranking & Competency \\
\hline \multirow{2}{*}{$\begin{array}{l}\text { Knowledge of square } \\
\text { metre method }\end{array}$} & Valuer & 33 & 4.61 & 1 & Expert \\
\hline & Quantity Surveyor & 27 & 4.44 & 2 & Expert \\
\hline \multirow{2}{*}{$\begin{array}{l}\text { Knowledge of rough } \\
\text { inclusive method }\end{array}$} & Valuer & 18 & 2.94 & 6 & Novice \\
\hline & Quantity Surveyor & 27 & 3.96 & 5 & Novice \\
\hline \multirow{2}{*}{$\begin{array}{l}\text { Knowledge of storey } \\
\text { enclosure method }\end{array}$} & Valuer & 16 & 2.56 & 7 & $\begin{array}{c}\text { Fundamental } \\
\text { awareness }\end{array}$ \\
\hline & Quantity Surveyor & 27 & 4.07 & 4 & Intermediate \\
\hline \multirow{2}{*}{$\begin{array}{l}\text { Knowledge of cube } \\
\text { method }\end{array}$} & Valuer & 20 & 1.85 & 8 & $\begin{array}{c}\text { Fundamental } \\
\text { awareness }\end{array}$ \\
\hline & Quantity Surveyor & 27 & 3.85 & 8 & $\begin{array}{c}\text { Fundamental } \\
\text { awareness }\end{array}$ \\
\hline \multirow{2}{*}{$\begin{array}{l}\text { Knowledge of elemental } \\
\text { method }\end{array}$} & Valuer & 17 & 3.18 & 4 & Advanced \\
\hline & Quantity Surveyor & 27 & 4.26 & 3 & Advanced \\
\hline \multirow{2}{*}{$\begin{array}{l}\text { Knowledge of } \\
\text { comparative method }\end{array}$} & Valuer & 23 & 4.17 & 2 & Expert \\
\hline & Quantity Surveyor & 27 & 3.93 & 6 & Novice \\
\hline \multirow{2}{*}{$\begin{array}{l}\text { Knowledge of } \\
\text { interpolation method }\end{array}$} & Valuer & 21 & 3.14 & 5 & Novice \\
\hline & Quantity Surveyor & 27 & 3.89 & 7 & $\begin{array}{c}\text { Fundamental } \\
\text { awareness }\end{array}$ \\
\hline \multirow{2}{*}{$\begin{array}{l}\text { Knowledge of built } \\
\text { drawings }\end{array}$} & Valuer & 20 & 4.00 & 3 & Advanced \\
\hline & Quantity Surveyor & 27 & 4.67 & 1 & Expert \\
\hline
\end{tabular}

Table 2 ranks the level of competency as regards the cost estimating methods between valuers and quantity. The findings show that valuers are most competent in the use of the square metre method while quantity surveyors are most competent in the use of built drawing methods. This is evidenced by the mean score of 4.61 and 4.67. In the use of cube, rough inclusive and interpolation methods, both professionals have a poor competency level as the low mean scores of 2.94, 3.96, $1.85,3.85,3.14$ and 3.89 seem to suggest. A sharp contrast in competency levels between valuers and quantity surveyors in the use of the comparative method suggests that valuers with a mean score of 4.17 are more competent than quantity surveyors with a mean score of 3.93. From the findings, it can be inferred that both professionals seem to be very competent with older methods of cost estimating and although they might have an idea of contemporary methods of cost estimating, making use of them is another problem entirely. 
Table 3. Descriptive Statistics on Level of Expertise in Cost Estimating Methods between Valuers and Quantity Surveyors (developed by the authors)

\begin{tabular}{|l|l|c|c|r|r|}
\hline & Profession & $\mathrm{N}$ & \multicolumn{1}{c|}{ Mean } & Std. deviation & \multicolumn{1}{c|}{ Std. error mean } \\
\hline $\begin{array}{l}\text { Cost estimating } \\
\text { method }\end{array}$ & Valuer & 8 & 3.3063 & 0.90888 & 0.32134 \\
\cline { 2 - 7 } & $\begin{array}{l}\text { Quantity } \\
\text { Surveyor }\end{array}$ & 8 & 4.1338 & 0.29592 & 0.10462 \\
\hline
\end{tabular}

Source: Data Analysis, 2018

Table 3 shows the mean of both professionals as regards their level of expertise on cost estimating methods. The mean score of 4.1338 for quantity surveyors is higher than the mean score of 3.3063 for valuers. This means that there is going to be a significant difference here and a t-test carried will suggest whether to reject the null and go with the research hypothesis posed earlier in the work.

Table 4. Variance and Independent Samples Test of the Level of Expertise in Cost Estimating Methods between Valuers \& Quantity Surveyors (developed by the authors)

\begin{tabular}{|c|c|c|c|c|}
\hline & & & \multicolumn{2}{|c|}{ Cost estimating methods } \\
\hline & & & $\begin{array}{c}\text { Equal variances } \\
\text { assumed }\end{array}$ & $\begin{array}{c}\text { Equal variances } \\
\text { not assumed }\end{array}$ \\
\hline \multirow{2}{*}{$\begin{array}{l}\text { Levene's test for } \\
\text { equality of } \\
\text { variances } \\
\end{array}$} & \multicolumn{2}{|l|}{$\mathrm{F}$} & 6.84 & \\
\hline & \multicolumn{2}{|l|}{ Sig. } & 0.02 & \\
\hline \multirow{7}{*}{$\begin{array}{l}\text { t-test for equality } \\
\text { of means }\end{array}$} & \multicolumn{2}{|l|}{$\mathrm{t}$} & -2.449 & -2.449 \\
\hline & \multicolumn{2}{|l|}{ df } & 14 & 8.468 \\
\hline & \multicolumn{2}{|c|}{ Sig. (2-tailed) } & 0.028 & 0.038 \\
\hline & \multicolumn{2}{|c|}{ Mean difference } & -0.8275 & -0.8275 \\
\hline & \multicolumn{2}{|c|}{ Std. error difference } & 0.33794 & 0.33794 \\
\hline & \multirow{2}{*}{$\begin{array}{c}95 \% \text { Confidence } \\
\text { interval of the } \\
\text { difference }\end{array}$} & Lower & -1.55231 & -1.59936 \\
\hline & & Upper & -0.10269 & -0.05564 \\
\hline
\end{tabular}

From Table 4 above, our Sig ( $p$-value) for the F-test is 0.20 that is less than our alpha value of 0.05 . Therefore, we can conclude that there is no homogeneity of variance in the competency levels of cost estimating methods between the two groups of professionals. Using the bottom row to determine the equality of means, we find our t-test to be -2.449 and its corresponding $p$-value of 0.038 to be less than our alpha value of 0.05 . We can therefore reject the null and conclude that there is significant evidence to support difference in the level of expertise in cost estimating methods between valuers and quantity surveyors. 


\section{CONCLUSION}

From the findings above, it is clear that there are problems still militating against the use of the DRC method by valuers in Nigeria today. In the past, it was believed that one of the major problems hampering the use of the DRC method was arriving at the appropriate depreciation rate but research showed that valuers wew particularly inept at cost estimating techniques. This study therefore underscores the need to assess the level of competence in cost estimating techniques among valuers and quantity surveyors. In particular, the study has found out that valuers need the input of quantity surveyors when accurately determining reinstatement cost as valuers do not possess the professional skills to determine the reinstatement cost by accurately valuing properties using the DRC method. It has been observed that although the valuer may possess some basic knowledge of cost estimating techniques, the quantity surveyor has a more superior knowledge and level of competence in this regard. Findings of the research also reveal that valuers rarely work with quantity surveyors on briefs concerning valuation. Information about cost estimates when carrying out valuation involving the use of DRC method is usually otained from comparable buildings and 'the word of mouth' of other valuers. Hence, there is a need for both valuers and quantity surveyors to work in tandem to perfect valuation briefs involving the use of the DRC method. Gone are the days when valuation reports were accepted without scrutiny. Due to the nature of the Nigerian economy, at present financial institutions need to be certain that prospective loan seekers have the required collateral (which most of the time is building) to service the loans granted to them. Therefore, it is recommended that NIESV in conjunction with NIQS should organise seminars to educate valuers and quantity surveyors alike on current cost estimating methods. On their own part, valuers should always seek out the services of quantity surveyors when in doubt about the unit cost of a building to be valued so as to ensure that the desired results are achieved. It is important that both professionals work together as in recent times even quantity surveyors and the general public have ignorantly come to attribute cost to value in valuation. This blunder can be averted if there is a healthy interaction between both professionals. No man is an island of knowledge and as such valuers should brush up their knowledge of these cost estimation methods and in the event they are not sure of how to accurately determine cost estimates for their valuation, reach out to the quantity surveyors who possess the requisite skill for cost estimating. It is an open secret in Nigeria today that the quantity surveying profession is a very young one as very few tertiary institutions offer quantity surveying as a course. Even the ones offering do not have estate management students offering any courses in quantity surveying; hence, there is ignorance on the part of valuers about the functions of quantity surveyors and requisite knowledge required in cost-estimating when carrying out valuation using the DRC method. The NIQS and the Quantity Surveyors Registration Board of Nigeria (QSRBN) should organise campaigns geared at enlightening the public on the roles of quantity surveyors in the society. NIQS should also work closely with government and the Nigerian University Commission (NUC) to see how the study of quantity surveying can be introduced to more universities. ESVARBON (Estate Surveying and Valuation Registration 
Board of Nigeria), the body in charge of setting up curriculum for the study of estate management at universities in Nigeria, needs to review the present curriculum together with the NUC and incorporate the study of certain courses in quantity surveying especially in the preliminary and intermediary years of the life of the estate management undergraduate so they can be grounded in some aspects of the quantity surveying profession. The built-up profession is an inter-disciplinary one and the exchange of knowledge between all professionals in it should be welcomed and greatly encouraged. Valuers working with quantity surveyors to perfect valuation briefs involving the use of the DRC method will not only produce more accurate figures but also help strengthen the confidence the general public reposes in the abilities of both professionals. The present research focused on Lagos state, with results obtained from Nigeria. Further research might find it useful to compare the results obtained in Nigeria with results of similar studies in other countries, to find the common tendencies in selection of the evaluation methods.

\section{REFERENCES}

Aihie, V. U., \& Ikuabe, M. (2018). Estimating the reinstatement or replacement cost in valuation: A case for the estate surveyor and quantity Surveyor to work in tandem in perfecting valuation briefs When using the contractor's method (Depreciated Replacement Cost Method) in determining the value of Properties, International Journal of Civil Engineering, Construction and Estate Management, 6(1), 26-39.

Akomolede, K. (2004). Business Valuation: The Practice versus the Theories and the Way Forward. Paper presented at the Continuing Professional Development Workshop organized by the Nigerian Institution of Estate Surveyors and Valuers held in Lagos, Kaduna and Enugu.

American Society of Appraisers (2009). ASA Business Valuation Standards. Retrieved from https://www.appraisers.org/docs/default-source/discipline_bv/bv-standards.pdf?sfvrsn=0

Ashworth, A. \& Perera, S. (2015). Cost Studies of Buildings (6 ${ }^{\text {th }}$ ed.). Abingdon, Oxon: Routledge. https://doi.org/10.4324/9781315708867

Bello, M. O. \& Bello, V. A. (2007). The Influence of Contemporary Models on Valuation Practice in Nigeria, Hong Kong SAR, TS 3C- Valuation Practice, Strategic Integration of Survey of Services, FIG Week, 13-17.

Blogspot.com. Quantity Surveying. Retrieved from www.qskiru.blogspot.com (2010, October 2)

Breedt, J. (2010). "Estimating: A valid exercise or a false sense of security?" An unpublished B.Sc dissertation submitted to the Department of Built Environment and Information Technology University of Pretoria, South-Africa.

Brook, M. (2017). Estimating and tendering for construction work (5 $5^{\text {th }}$ ed.). Abingdon, Oxon: Routledge.

Coates S. J, \& Steed L. G. (2001). SPSS Analysis without Anguish (10 ${ }^{\text {th }}$ ed.). Sydney, Australia: John Wiley and Sons Ltd.

Ekenta, C., \& Iroham, C. O. (2014). Challenges of mortgage valuation in Port Harcourt, Nigeria. Issues in Business Management and Economics 2(4), 074-079.

Estate Surveyors and Valuers (Registration, Etc.) Act. CAP 111, Laws of the Federation of Nigeria1990.

Field, A. (2005). Discovering Statistics Using SPSS, London: Sage Publications.

French, N., \& Gabrielli, L. (2007). Market value and depreciated replacement cost: contradictory or complementary?, Journal of Property Investment \& Finance, 25(5), 515-524. https://doi.org/10.1108/14635780710776693

Hore, A. V., Kehoe, J. G., McMullan, R., \& Penton, M. R. (1997). Construction 1: Management finance Measurement. Hong Kong: Macmillan Press Ltd. https://doi.org/10.1007/978-1-34913932-3

Ifediora, G. S. (2009). Appraisal Framework: Institute for Development Studies, Enugu, Nigeria. 
IVSC. (2017). International Valuation Standards, International Valuation Standard Council, London. Retrieved from https://www.ivsc.org/standards/international-valuationstandards/consultation/IVS-review

Jagboro, G. O. (2016). Unmasking the Tower of Babel and the Scourge of Abandoned Projects in Nigeria, Obafemi Awolowo University, Ile-Ife, Inaugural lecture series 286.

Kuye, O. (2011). Estate Office Practice ( $2^{\text {nd }}$ Edition). AdroDadar Heritage Company Limited, Lagos, Nigeria.

National Institutes of Health. Office of Human Resources. Retrieved from www.hr.nih.gov (2018, September 2)

NCSS Ltd. NCSS Statistical Software. Retrieved from www.ncss.com (2018, September 2)

Nigerian Institute of Quantity Surveyors (NIQS) (2015), Vision Statement, 2015 Dairy.

Nkado, R. N. (2000). Competencies of Professional Quantity Surveyors in a Developing Economy, Retrieved

from http://citeseerx.ist.psu.edu/viewdoc/download?doi=10.1.1.199.1152\&rep=rep1\&type=pdf

Ogunba, O. (2011). Valuers' perceptions of depreciation models in DRC valuations. Journal of Property Investment \& Finance, 29(2), 190-209. https://doi.org/10.1108/14635781111112792

Okorie, A, Daniel, D. I., \& Abdullahi, I. (2012). Mortgage investment in Osun State: An Evaluation of the Role of Estate Surveyors and Valuers In: Laryea, S., Agyepong, S.A., Leiringer, R. and Hughes, W. (Eds) Procs 4th West Africa Built Environment Research (WABER) Conference, 24-26, Abuja, Nigeria, 1085-1094.

Olatunde, J. (2006). New Opportunities for Quantity Surveyors in Nigeria Business Environment, $21^{\text {st }}$ Century Quantity Surveying, Agenda for the Future, NIQS Biennial. 1-3 November.

Olatunde, N. A., \& Okorie, V. N. (2016). Appraisal of Awareness Level of Quantity Surveying Profession among Secondary School Students in Benin City, Nigeria. International Journal of Advanced Engineering, Management and Science (IJAEMS), 2(8), Aug- 2016.

Olunloyo, O. A. (2012). Mitigating informal economic sectors' proliferation through microcredit scheme for small and medium scale entrepreneurs in metropolitan Lagos In: Laryea, S., Agyepong, S. A., Leiringer, R. and Hughes, W. (Eds), Proceedings in 4th West Africa Built Environment Research (WABER) Conference, 24-26 July 2012, Abuja, Nigeria, 1155-1167.

Onyejiaka, J. C., Emoh, F. I., \& Egolum, C. C. (2012). Developing a Database for Efficient Property Valuation in Nigeria, Journal of the Nigerian Institution of Estate Surveyors and Valuers. 36(2), pp. 22-23.

Pienaar, J. S. (2004). Construction Cost Management Part1: Estimating and Pricing Revision 6. Pretoria: University of Pretoria.

Plimmer F., \& Sayce S. (2006). Depreciated Replacement Cost: Consistent Methodology? Shaping the Change XXIII FIG Congress, Munich, Germany.

Seeley, I. H. (1976). Building economics. ( $3^{\text {rd }}$ ed.) London: The Macmillan Press Ltd. https://doi.org/10.1007/978-1-349-03068-2

Shapiro, E., Mackmin, D., \& Sams, G., (2012). Modern methods of valuation. (11 $1^{\text {th }}$ ed), Oxford: Estates Gazette.

Simon-Eigbe, B. O. (2003). Introduction to Tendering and Estimating, Benin City, Edo state: Olive Publishers.

Udechukwu, C. E. (2009). Principles of Valuation, Lagos, Nigeria: Treem Nigeria Limited.

Whipple, R. (1995). Property Valuation and Analysis, Sydney: The Law Book Company.

Wyatt, P. (2009). Replacement cost and market value, Journal of Property Investment \& Finance, 27(6), 593-602. https://doi.org/10.1108/14635780910993186

\section{AUTHORS' SHORT BIOGRAPHIES}

Vincent Uwaifiokun Aihie (Jnr) received the B.Sc. degree in Estate Management from the University of Nigeria, Nsukka in 2012 and received the M.Sc. degree in Real Estate from Henley Business School, University of Reading in 2016. He is currently a Lecturer at the Department of Estate Management of the Faculty of Environmental Sciences, University of Benin, Benin City and before assuming duty as a Lecturer in 2014, he worked as a Pupil Surveyor and Graduate Surveyor 
at various estate valuation firms. His research areas are valuation, real estate economics, urban planning \& sustainability, housing economics and corporate real estate.

He is currently an Associate Member of the Nigerian Institution of Estate Surveyors \& Valuers (NIESV) and registered Estate Surveyor \& Valuer with the Estate Surveyors \& Valuers Registration Board of Nigeria (ESVARBON). E-Mail: uwaaihie@yahoo.com

Matthew Ikuabe received the B.Tech degree in quantity surveying frome the Federal University of Technology, Akure in 2012 and equally received the M.Tech in quantity surveying from the Federal University of Technology, Akure in 2018.

He is currently a Lecturer at the Department of Quantity Surveying, Faculty of Environmental Sciences, University of Benin, Benin City. Prior to the present position at the university, he worked as a Resident Quantity Surveyor at Malpha Construction Ltd, a construction contracting outfit situated in Lagos, Nigeria. His research areas include construction cost management, procurement studies, value management, quantity surveying practices and contract administration.

He is currently a Probationer Member of the Nigerian Institute of Quantity Surveyors (NIQS).

E-Mail: matthew.ikuabe@uniben.edu 